\title{
Mini-Review: Cabozantinib in the Treatment of Advanced Renal Cell Carcinoma and Hepatocellular Carcinoma
}

This article was published in the following Dove Press journal: Cancer Management and Research

\author{
Nityam Rathi \\ Benjamin L Maughan \\ Neeraj Agarwal (D) \\ Umang Swami (iC)
}

Division of Oncology, Department of Internal Medicine, Huntsman Cancer Institute, University of Utah, Salt Lake City, UT, USA
Correspondence: Neeraj Agarwal Genitourinary Oncology Program, Huntsman Cancer Institute, University of Utah, Salt Lake City, UT, USA

Email neeraj.agarwal@hci.utah.edu

Umang Swami

Department of Oncology, Huntsman

Cancer Institute, University of Utah, Salt

Lake City, UT, USA

Email umang.swami@hci.utah.edu

\begin{abstract}
Cabozantinib is an oral, tyrosine-kinase inhibitor with potent activity against VEGFR2 and MET, along with multiple other tyrosine kinases involved in cancer development and progression. Herein, we will focus on preclinical and clinical studies leading to the approval of cabozantinib in advanced renal cell carcinoma and hepatocellular carcinoma. Covered studies include NCT01100619, CABOSUN, METEOR, NCT00940225 and the CELESTIAL trial. Finally, we review future directions of cabozantinib development by highlighting some ongoing clinical trials.
\end{abstract}

Keywords: cabozantinib, renal cell carcinoma, hepatocellular carcinoma, kidney cancer, liver cancer, cabozantinib resistance mechanism

\section{Introduction}

Receptor tyrosine kinases (RTKs) are key regulators of cellular proliferation, differentiation, survival, migration, and metabolism. ${ }^{1}$ Mutations and other genomic alterations can lead to aberrant activation of RTKs, causing dysregulated cell signaling that promotes angiogenesis, proliferation, and protection from apoptosis; resulting in tumor growth and metastasis. ${ }^{1}$ Vascular endothelial growth factor (VEGF) is one of the RTK subfamilies that plays a major role in angiogenesis. ${ }^{2}$ Hypoxia, common within the tumor microenvironment, activates hypoxia-inducible factors (HIF-1 $\alpha$ and HIF- $\beta$ ) that up-regulate transcription of pro-angiogenic genes, including VEGF and its receptors VEGFR1 and VEGFR2. ${ }^{3}$ Thus, VEGF is an attractive target in tumors that overexpress VEGF, or are dependent on this signaling pathway.

Multiple small molecule inhibitors or antibodies of VEGF are clinically available to treat multiple cancer types, including hepatocellular carcinoma and renal cell carcinoma. However, these therapies are not curative, and resistance inevitably develops. One resistance mechanism includes activation of the hepatocyte growth factor (HGF)-MET pathway, thereby restoring proliferation and angiogenesis, in a hypoxia-independent manner. $^{4}$

Cabozantinib is an oral, small-molecule tyrosine kinase inhibitor (TKI) with potent activity against VEGFR2 and MET, along with other RTKs such as RET, KIT, AXL, TIE2, ROS1, TYRO3, MER, TRKB, and FLT3 that are involved in cancer development and progression., ${ }^{5,6}$ The capsular formulation Cometriq $^{\circledR}$ is approved for the treatment of medullary thyroid cancer, and Cabometyx ${ }^{\circledR}$ is approved in renal cell carcinoma and second-line treatment of hepatocellular 
carcinoma. $^{7}$ This review will discuss cabozantinib $\left(\right.$ Cabometyx ${ }^{\circledR}$ ) treatment for both renal cell carcinoma and hepatocellular carcinoma.

\section{Development of Cabozantinib in Advanced Renal Cell Carcinoma}

$3 p$ loss is the first genomic event in sporadic renal cell carcinoma for the majority of patients and is lost in greater than $90 \%$ of RCC. The $3 p$ chromosome encodes for many tumor suppressors important for this disease, including Von Hippel Lindau (VHL), PBRM1, BAP1 and SETD2. The VHL gene is the most commonly mutated gene (approximately $80 \%$ ) in clear cell renal cell carcinoma (ccRCCC). ${ }^{8}$ Pathogenic loss of VHL function is an early event in the development of ccRCC. ${ }^{9}$ It leads to constitutive stabilization and activation of hypoxiainducible factor, resulting in excessive production of proangiogenic factors such as VEGF, FGF, and PDGF; downregulation of E-cadherin; induction of epithelial to mesenchymal transition; and activation of hepatocyte growth factor receptor (HGFR, encoded by MET) or alteration of downstream MET signaling. ${ }^{9}$

In cellular assays, cabozantinib has shown to potently inhibit MET and VEGFR2 phosphorylation at nanomolar concentrations, resulting in decreased in vitro cell invasion. ${ }^{5}$ The $\mathrm{IC}_{50}$ values of cabozantinib for MET, VEGFR2, KIT, RET, AXL, TIE2, and FLT3 are 1.3, 0.035, 4.6, 5.2, 7, 14.3, and 11.3 $\mathrm{nmol} / \mathrm{L}$, respectively. Potent inhibition of these RTKs leads to disruption of angiogenesis, inhibition of tubule formation, tumor migration-causing disruptions in tumor vasculature, and extensive endothelial and tumor cell apoptosis. ${ }^{5}$ In in vivo experiments, in $\mathrm{H} 441$ tumors that constitutively harbor phosphorylated MET, a single oral dose of $100 \mathrm{mg} / \mathrm{kg}$ cabozantinib resulted in MET inhibition within 8 hours. ${ }^{5}$ In preclinical RCC models, cabozantinib has shown to rescue acquired sunitinib resistance by suppressing the expression and inhibiting the activation of AXL and/or MET. ${ }^{10}$

Cabozantinib has a long plasma half-life of approximately 120 hours and accumulates five-fold by day 15 , with daily dosing based on the area under the curve of the plasma concentration-time function. ${ }^{7}$ Cabozantinib plasma concentrations increase proportionally with increasing drug concentrations over the $20-60 \mathrm{mg}$ tablet range, but only marginally when comparing the $60 \mathrm{mg}$ dose to the $140 \mathrm{mg}$ dose. ${ }^{11}$ It is a substrate of CYP3A4 and multidrug resistance protein 2 (MRP2) in vitro. Therefore, inhibitors of CYP3A4 and MRP2, along with high-fat diet or hepatic impairment, can increase its systemic exposure. , $12,13^{-13}$

\section{Phase I Trials}

A single-arm, open-label phase I trial (NCT01100619) enrolled 25 heavily pretreated metastatic ccRCC patients to evaluate the safety and tolerability of cabozantinib. ${ }^{14}$ The most common grade 3 or worse side effects were hypophosphatemia (40\%), fatigue (20\%), hyponatremia (20\%), diarrhea $(12 \%)$, and lipase elevation (12\%). Grade 3 or worse proteinuria $(8 \%)$, palmar-plantar erythrodysesthesia $(4 \%)$, pulmonary embolism (12\%), and hypertension (4\%) were also reported. Common grade 1 or 2 side effects also included hypothyroidism (48\%) and hypertension (32\%). These side effects are frequently seen with other VEGF antagonistic TKIs used in the treatment of metastatic ccRCC. ${ }^{15,16}$ As summarized in Table 1, cabozantinib demonstrated a significant overall response rate (ORR) of $28 \%$ (7 of 25 patients), and a promising median progression-free survival (PFS) of 12.9 months and median overall survival (OS) of 15 months. ${ }^{14}$

\section{Phase III METEOR - the Registration Trial of Cabozantinib in Metastatic Renal Cell Carcinoma}

The METEOR trial was a randomized phase III study that compared the efficacy of cabozantinib with everolimus in patients with advanced ccRCC who progressed after at least one VEGF-targeted therapy. ${ }^{17}$ Of the 658 enrolled patients, 330 were randomized to to the cabozantinib arm and 328 to the everolimus arm. The trial was powered for both the primary endpoint of PFS and the secondary endpoint of OS. Safety and ORR were other secondary endpoints. Median PFS and ORR were determined in the first 375 randomized patients. Both endpoints favored cabozantinib compared to everolimus (Table 1). ${ }^{17}$ The median OS was 21.4 months with cabozantinib and 17.1 months with everolimus (HR 0.70 ; 95\% CI 0.58-0.85; $\mathrm{p}=0.0002) .{ }^{18}$ For all subgroups evaluated, the point estimates favored cabozantinib over everolimus for both PFS and OS, including IMDC risk categories (favorable, intermediate and poor), age, the number of prior therapies, prior immune therapy use and presence of visceral metastasis among others. ${ }^{18,19}$

Cabozantinib improved PFS, OS, and ORR as compared to everolimus regardless of age group $(<65,65-74, \geq 75$ years) ${ }^{20} \mathrm{~A}$ recent network meta-analysis further demonstrated that salvage cabozantinib may offer the best survival outcomes in elderly ( $\geq 65$ years) metastatic RCC patients. ${ }^{21}$ In another subgroup analysis, cabozantinib improved outcomes irrespective of prior antiangiogenic therapy (sunitinib or pazopanib) or prior use of checkpoint inhibitor therapy. ${ }^{22}$ On survival analysis based on PD-L1 expression, cabozantinib improved survival outcomes regardless of the PD-L1 
expression profile. In PD-L1 positive patients $(\geq 1 \%)$, cabozantinib had a non-statistically significant longer median PFS (5.6 months vs 3.7 months; HR 0.66 95\% CI 0.40-1.11) and longer median OS (18.4 months vs 13.9 months, HR 0.82; 95\% CI $0.47-1.41$ ) as compared to everolimus. In PD-L1 negative patients, cabozantinib showed a longer median PFS (8.5 months vs 4.1 months; HR $0.46,95 \%$ CI $0.32-0.66$ ) and OS (not reached vs 18.4 months, HR $0.58,95 \%$ CI $0.38-0.88){ }^{23}$ However, in the combined analysis of CABOSUN and METEOR trials, MET and/or PD-L1 expression were not found to be significant predictors of benefit from cabozantinib $(P$ interaction $>0.20){ }^{23}$

Cabozantinib and everolimus had similar grade 3 or higher adverse event rates, $71 \%$ and $61 \%$, respectively. ${ }^{18}$ The most common grade 3 or higher adverse events for cabozantinib were hypertension (15\%), diarrhea (13\%), fatigue (11\%), and palmer-plantar erythrodysesthesia $(8 \%)$. The most common grade 3 or higher adverse events for everolimus were anemia $(17 \%)$, fatigue $(7 \%)$, hyperglycemia $(5 \%)$, and hypertension $(4 \%)$. Dose reductions with cabozantinib occurred in $64 \%$ of patients, while dose reductions with everolimus occurred in only $25 \%$ of patients. Treatment discontinuation due to adverse events was relatively similar between cabozantinib (13\%) and everolimus (11\%).

\section{Phase II CABOSUN Trial}

The CABOSUN trial was a randomized phase II clinical trial evaluating first-line cabozantinib for International Metastatic RCC Database Consortium (IMDC) intermediate or poor risk ccRCC patients. ${ }^{24,25}$ The study randomized 157 patients with newly diagnosed mccRCC 1:1 to cabozantinib $(n=79)$ or sunitinib $(n=78)$. PFS was assessed as the primary endpoint, and secondary endpoints included OS, ORR, and safety. Cabozantinib showed a superior median PFS of 8.6 months, as compared to 5.3 months with sunitinib (hazard ratio [HR] 0.48, 95\% CI $0.31-0.74 ; \mathrm{p}=0.0008$ ), per independent radiology review. ${ }^{25}$ Cabozantinib, as compared to sunitinib, also showed a non-statistically significant higher median OS (26.6 months vs 21.2 months, HR $0.80 ; 95 \%$ CI

Table I Selected Cabozantinib Trials in Metastatic Clear Cell Renal Cell Carcinoma with Survival Results

\begin{tabular}{|c|c|c|c|c|c|}
\hline Trial with Survival Results & NCT01100619 14 & \multicolumn{2}{|l|}{ CABOSUN ${ }^{23,24}$} & \multicolumn{2}{|l|}{ METEOR ${ }^{17-18}$} \\
\hline Phase & 1 & \multicolumn{2}{|l|}{$\|$} & \multicolumn{2}{|l|}{ III } \\
\hline Primary Endpoint & Safety/Tolerability & \multicolumn{2}{|l|}{ PFS, as per IRC } & \multicolumn{2}{|l|}{ PFS, as per IRC } \\
\hline $\begin{array}{l}\text { Treatment arms (number of } \\
\text { patients) }\end{array}$ & Cabozantinib (N=25) & Cabozantinib ( $N=79)$ & Sunitinib $(N=78)$ & $\begin{array}{l}\text { Cabozantinib } \\
(\mathrm{N}=330)\end{array}$ & $\begin{array}{l}\text { Everolimus } \\
(\mathrm{N}=328)\end{array}$ \\
\hline mPFS (months) $(95 \% \mathrm{Cl})$ & $12.9(\mathrm{~N} / \mathrm{A})$ & $8.6(6.8-14.0)$ & $5.3(3.0-8.2)$ & $7.4(5.6-9.1)$ & $3.8(3.7-5.4)$ \\
\hline HR of mPFS ( $95 \% \mathrm{Cl})$; P-value & N/A & \multicolumn{2}{|l|}{$0.48(0.31-0.74) ; 0.0008$} & \multicolumn{2}{|c|}{$0.58(0.45-0.75) ;<0.001$} \\
\hline ORR (\%) (95\% Cl) & $28(N / A)$ & $20(12-30.8)$ & $9(3.7-17.6)$ & $17(13-22)$ & $3(2-6)$ \\
\hline mOS (months) $(95 \% \mathrm{Cl})$ & $15.0(\mathrm{~N} / \mathrm{A})$ & 26.6 (I4.6-NE) & $21.2(16.3-27.4)$ & $21.4(\mathrm{~N} / \mathrm{A})$ & $17.1(\mathrm{~N} / \mathrm{A})$ \\
\hline HR of mOS ( $95 \% \mathrm{Cl})$; P-value & N/A & \multicolumn{2}{|l|}{$0.80(0.53-1.21) ; \mathrm{N} / \mathrm{A}$} & \multicolumn{2}{|c|}{$0.70(0.58-0.85) ; 0.0002$} \\
\hline IMDC Favorable (\%) & 12 & 0 & 0 & 43 & 44 \\
\hline IMDC Intermediate (\%) & 80 & 81 & 81 & 43 & 40 \\
\hline IMDC Poor (\%) & 8 & 19 & 19 & 14 & 16 \\
\hline Any grade adverse events (\%) & N/A & 96 & 99 & 100 & $>99$ \\
\hline $\begin{array}{l}\text { Most common all grade } \\
\text { adverse events (\%) }\end{array}$ & $\begin{array}{l}\text { Fatigue (80), Diarrhea } \\
(64), \\
\text { Hypophosphatemia } \\
(60)\end{array}$ & $\begin{array}{l}\text { Fatigue (85.9), Hypertension } \\
(80.8) \text {, Diarrhea (71.8) }\end{array}$ & $\begin{array}{l}\text { Fatigue (81.9), Hypertension } \\
\text { (68.1), Diarrhea (52.8) }\end{array}$ & $\begin{array}{l}\text { Diarrhea }(74) \text {, } \\
\text { Fatigue }(56), \\
\text { Nausea }(50)\end{array}$ & $\begin{array}{l}\text { Fatigue (46), } \\
\text { Anemia (38), } \\
\text { Decreased } \\
\text { appetite (34) }\end{array}$ \\
\hline $\begin{array}{l}\text { Most common grade } 3-5 \\
\text { adverse events (\%) }\end{array}$ & $\begin{array}{l}\text { Hypophosphatemia } \\
(40) \text {, Fatigue (20), } \\
\text { Hyponatremia (20) }\end{array}$ & $\begin{array}{l}\text { Hypertension (28.2), Diarrhea } \\
\text { (I0.3), Palmar-Plantar } \\
\text { Erythrodysesthesia (7.7) }\end{array}$ & $\begin{array}{l}\text { Hypertension (22.2), Fatigue } \\
\text { (15.3), Diarrhea (II.I), } \\
\text { Thrombocytopenia (II.I) }\end{array}$ & $\begin{array}{l}\text { Hypertension } \\
\text { (I5), Diarrhea } \\
\text { (I3), Fatigue (II) }\end{array}$ & $\begin{array}{l}\text { Anemia (17), } \\
\text { Fatigue (7), } \\
\text { Hyperglycemia (5) }\end{array}$ \\
\hline
\end{tabular}

Abbreviations: PFS, progression-free survival; OS, overall survival; ORR, overall response rate; IRC, Independent Radiology Review Committee; IMDC, International Metastatic RCC Database Consortium; HR, hazard ratio; $\mathrm{Cl}$, confidence interval. 
0.53-1.21), higher ORR ( $20 \%$ vs $9 \%$ ), and similar grade 3 or higher adverse events (AEs, $68 \%$ vs $65 \%$ ) (Table 1 ). ${ }^{25}$

Similar trends were observed upon stratifying patients based on MET expression. In patients with MET-positive tumors (defined as $\geq 50 \%$ of tumor cells staining $2+$ or $3+$ by immunohistochemistry), cabozantinib showed a higher median PFS of 13.8 months, as compared to 3.0 months with sunitinib (HR 0.32; 95\% CI, 0.16-0.63). For MET-negative patients, the median PFS was 6.9 months with cabozantinib and 6.1 months with sunitinib (HR 0.67; 95\% CI 0.37-1.23). ${ }^{25}$ When stratified based on IMDC risk groups and the presence of bone metastases, cabozantinib was consistently favored. ${ }^{24}$ In another subgroup analysis, improved survival with cabozantinib was observed in patients, regardless of the PD-L1 expression profile. In PD-L1 positive patients ( $\geq 1 \%$ expression score), cabozantinib had a non-statistically significant longer median PFS (8.4 months vs 3.1 months; HR 0.46 95\% CI $0.18-1.21)$ and similar OS (18.1 months vs 21 months, HR $0.8595 \%$ CI 0.31-2.31), as compared to sunitinib. In PD-L1 negative patients, cabozantinib showed a longer median PFS (11 months vs 5 months; HR $0.47,95 \%$ CI $0.26-0.86$ ) and a non-statistically significant longer median OS (30.3 months vs 22.4 months, HR $0.71,95 \%$ CI $0.39-1.29$ ), as compared to sunitinib. ${ }^{23}$

\section{Cabozantinib in Hepatocellular Carcinoma}

HGF is known to be a potent mitogen for primary hepatocytes, and the HGF/MET axis plays an important role in liver development and regeneration. ${ }^{26}$ In vitro, MET knockdown was shown to prevent MHCC97-L cells from proliferating by arresting cells at the $\mathrm{G}_{0}-\mathrm{G}_{1}$ phase. ${ }^{27}$ In vivo, overexpression of the MET RTK allowed for its activation in an HGFindependent manner, and induced HCC. ${ }^{27}$ Overexpression of mRNAs for the MET receptor has been noted in poorly differentiated tumors and in HCC patients with early tumor recurrence. ${ }^{28}$ Sorafenib, a VEGFR inhibitor was the only approved first-line systemic therapy for HCC until 2018. ${ }^{29}$ One of the common resistance mechanisms involves activation of the HGF/MET axis. ${ }^{30}$ Therefore, the HGF/MET axis appears to be an attractive target in HCC treatment.

\section{Phase II Trials}

In a phase II placebo-controlled, randomized discontinuation study, 41 HCC patients were enrolled based on a criteria of Child-Pugh A liver function and prior treatment with $\leq 1$ systemic anticancer regimen. ${ }^{31,32}$ All patients received daily cabozantinib during a 12-week lead-in phase. At week 12, patients with stable disease (SD) were randomized to cabozantinib or placebo, patients with a partial response (PR) continued openlabel cabozantinib treatment, and patients with progressive disease (PD) at or before week 12 discontinued treatment. Primary endpoints included ORR at week 12 (lead-in phase) and PFS (randomized phase). In the entire cabozantinib-treated population, safety, tolerability, PFS, and OS served as secondary endpoints. The results demonstrated promising activity of cabozantinib in HCC (Table 2). In the lead-in phase, the ORR was only $5 \%$, and there were no complete responses. However, the disease control rate (partial response plus stable disease) was $66 \%$. In the randomized phase, where patients were randomized to receive cabozantinib versus placebo after the 12week treatment with cabozantinib, there was a numerical increase in the median PFS with cabozantinib (2.5 months, 95\% CI 1.3-6.8 months) as compared to placebo (1.4 months, 95\% CI, 1.3-4.2 months), although this difference was not statistically significant. The median PFS and OS from start of cabozantinib treatment for all patients enrolled in this trial were 5.2 and 11.5 months, respectively. Alpha-fetoprotein response (AFP, defined as a reduction from baseline by $>50 \%$ with AFP $>20 \mathrm{ng} / \mathrm{mL}$ at baseline) was observed in $35 \%$ ( 9 of 26 patients with $\geq 1$ post-baseline AFP levels) of patients treated with cabozantinib. While the trial had 9 cohorts of various disease types, with an initial enrollment plan to randomize 70 patients per cohort, randomization was halted early due to promising activity in the cabozantinib arm and symptomatic progression in individual patients in the placebo arm. ${ }^{31}$ These encouraging results in ORR, OS, and a high disease control rate led to the initiation of a phase III trial in HCC patients.

\section{Phase III CELESTIAL- the Registration Trial of Cabozantinib in Advanced HCC}

The CELESTIAL trial was a double-blinded, randomized phase III trial that compared cabozantinib with placebo in previously treated, advanced HCC patients who were not amenable to curative treatment. ${ }^{33} 707$ HCC patients, all of whom had previously received sorafenib, were randomized in a 2:1 ratio to receive daily cabozantinib $(\mathrm{n}=470)$ or placebo $(\mathrm{n}=237)$. Treatment was given until disease progression or unacceptable toxicity were observed. The primary endpoint was OS, and secondary endpoints were PFS and ORR. Patients treated with cabozantinib had improved outcomes, with a significantly longer median OS, PFS, and ORR (Table 2). There was a higher percentage of patients alive at $6,12,18$, and 24 months in the cabozantinib group as compared to the placebo group. Approximately $50 \%$ of patients in the cabozantinib arm, as compared to $13 \%$ in the placebo arm, had an AFP 
Table 2 Selected Clinical Studies of Cabozantinib in Hepatocellular Carcinoma

\begin{tabular}{|c|c|c|c|}
\hline $\begin{array}{l}\text { Trial with Survival } \\
\text { Results }\end{array}$ & NCT00940225 ${ }^{31}$ & \multicolumn{2}{|l|}{ CELESTIAL ${ }^{33}$} \\
\hline Phase & || Randomized Discontinuation & \multicolumn{2}{|l|}{ III } \\
\hline Primary Endpoint & $\begin{array}{l}\text { Lead-in stage: ORR Randomized stage: } \\
\text { PFS }\end{array}$ & \multicolumn{2}{|l|}{ os } \\
\hline Treatment arms & Cabozantinib $(\mathrm{N}=4 \mathrm{I})$ & Cabozantinib $(\mathrm{N}=470)$ & Placebo $(N=237)$ \\
\hline mPFS (months) $(95 \% \mathrm{Cl})$ & $5.2(\mathrm{~N} / \mathrm{A})$ & $5.2(4.0-5.5)$ & $1.9(1.9-1.9)$ \\
\hline $\begin{array}{l}\text { HR of mPFS }(95 \% \mathrm{Cl}) \text {; } \\
\text { P-value }\end{array}$ & $N / A$ & \multicolumn{2}{|l|}{$0.44(0.36-0.52) ;<0.001$} \\
\hline ORR (\%) $(95 \% \mathrm{Cl})$ & $5(N / A)$ & $4(N / A)$ & $<1(N / A)$ \\
\hline mOS (months) (95\% Cl) & $11.5(7.3-15.6)$ & $10.2(9.1-12.0)$ & $8.0(6.8-9.4)$ \\
\hline $\begin{array}{l}\text { HR of } \operatorname{mOS}(95 \% \mathrm{Cl}) \\
\text { P-value }\end{array}$ & $N / A$ & \multicolumn{2}{|l|}{0.76 (0.63-0.92); 0.005} \\
\hline ECOG $0(\%)$ & 44 & 52 & 55 \\
\hline ECOG I (\%) & 56 & 48 & 45 \\
\hline ECOG $2(\%)$ & 0 & $<1$ & 0 \\
\hline $\begin{array}{l}\text { Any grade adverse events } \\
\text { (\%) }\end{array}$ & 100 & 99 & 92 \\
\hline $\begin{array}{l}\text { Most common all-grade } \\
\text { adverse events (\%) }\end{array}$ & $\begin{array}{l}\text { Diarrhea (63), Hand-foot syndrome } \\
\text { (56), Fatigue (56) }\end{array}$ & $\begin{array}{l}\text { Diarrhea (54), Decreased appetite (48), Palmar- } \\
\text { Plantar Erythrodysesthesia (46) }\end{array}$ & $\begin{array}{l}\text { Fatigue (30), Abdominal pain (25), } \\
\text { Diarrhea (19), Constipation (19) }\end{array}$ \\
\hline $\begin{array}{l}\text { Most common } \geq \text { grade } 3 \\
\text { adverse events }(\%)\end{array}$ & $\begin{array}{l}\text { Diarrhea (20), Hand-foot syndrome } \\
\text { (15), Thrombocytopenia (15) }\end{array}$ & $\begin{array}{l}\text { Palmar-Plantar Erythrodysesthesia (17), } \\
\text { Hypertension (16), Diarrhea (10), Fatigue (10) }\end{array}$ & $\begin{array}{l}\text { Increase AST (6), Ascites (5), Anemia } \\
\text { (5) }\end{array}$ \\
\hline
\end{tabular}

Abbreviations: PFS, progression-free survival; OS, overall survival; ORR, overall response rate; $\mathrm{HR}$, hazard ratio; $\mathrm{Cl}$, confidence interval.

response (patients with baseline AFP $\geq 20 \mathrm{ng} / \mathrm{mL}$ and $\geq 20 \%$ decrease from baseline) at week $8 .{ }^{34}$ Common grade 3 or 4 AEs associated with cabozantinib included palmar-plantar erythrodysesthesia, hypertension, aspartate aminotransferase elevation, fatigue, and diarrhea.

The development of palmar-plantar erythrodysesthesia or grade 3 or greater hypertension was associated with prolonged OS and PFS, though there were some differences in baseline characteristics among comparator groups. ${ }^{35}$ Regarding quality of life assessments, cabozantinib was associated with a slight decrease in health utility initially, but an overall increase in health utility with continued treatment. ${ }^{36}$

\section{Mechanisms of Resistance to Cabozantinib}

Almost all patients ultimately develop resistance to cabozantinib. However, the current understanding of mechanisms of resistance to cabozantinib is limited and these mechanisms might be similar to those with other TKIs. ${ }^{37,38}$ In a prior study, ccRCC activation of the transcription factor SOX18 has shown to alleviate the inhibitory effects of cabozantinib. ${ }^{39}$ Identified mechanisms of resistance in prostate cancer include (1) "preexisting" or "de-novo resistance" where tumor-induced bone secretes proteins termed "osteocrines" that activate integrin signaling and give a survival advantage to tumor cells, ${ }^{40}$ (2) vascular heterogeneity contributing to formation of islet of resistant cells, ${ }^{41}$ (3) YAP/TBX5dependent induction of FGFR1 in tumor cells as a potential mechanism of acquired resistance, ${ }^{41,42}$ and (4) upregulation of secreted proteins including pappalysin, IGFBP2, WNT 16, and DKK1 by osteoblasts which increase the tumorigenicity of prostate cancer cells. ${ }^{43}$ In mutant TPR-MET transformed $\mathrm{Ba} /$ F3 cells, cabozantinib treatment has shown to give rise to a broad range of unique mutants, such as F1200 and G1163R, etc., that are associated with cabozantinib resistance. $^{44}$ In advanced RET-rearranged lung cancers, MDM2 amplification has been implicated in primary and acquired resistance to cabozantinib. ${ }^{45}$ In NTRK1 gene 
rearranged KM12 colorectal cancer cells, activation of IGF1R has shown to mediate resistance to cabozantinib, as have various NTRK1 mutations like G595R, G595L, L564H, F646I, and D679G. ${ }^{46}$

\section{Conclusions \& Future Directions}

Following the remarkable success of cabozantinib as a single agent, multiple ongoing clinical trials are evaluating the safety and efficacy of various combination regimens that include immune checkpoint inhibitors in advanced RCC and HCC. Tables 3-5 provide a summary of selected clinical studies.

In advanced or metastatic RCC, cabozantinib is being evaluated in combination with pembrolizumab (NCT03149822), avelumab (NCT03200587), and nivolumab (CheckMate 9ER, NCT03141177). COSMIC313 (NCT03937219) is evaluating cabozantinib with nivolumab and ipilimumab in patients with previously untreated advanced or metastatic RCC. The CANTATA (NCT03428217) study is analyzing cabozantinib in combination with the glutaminase inhibitor telaglenastat (CB-839) in RCC patients who progressed on one or two prior therapies in the advanced or metastatic setting. Cabozantinib as a second-line treatment in locally advanced or metastatic RCC patients who have progressed on first-line checkpoint inhibitors is being investigated in the CaboPoint (NCT03945773) trial. It is also being explored in non-clear cell RCC in combination with nivolumab (CA209-9KU, NCT03635892) and as a single agent postimmunotherapy (ANZUP, NCT03685448).

A large, multi-cohort Phase 1b study (NCT03170960) is evaluating the optimal dosing and efficacy of cabozantinib with atezolizumab in patients with locally advanced or

Table 3 Ongoing Clinical Trials Investigating Novel Combination Treatment Regimens for RCC

\begin{tabular}{|c|c|c|c|c|c|c|}
\hline Trial Name & Phase & Target Population & Treatment Arms & $\begin{array}{l}\text { Primary } \\
\text { Endpoint }\end{array}$ & Secondary Endpoint & $\begin{array}{l}\text { Estimated } \\
\text { Study } \\
\text { Completion } \\
\text { Date }\end{array}$ \\
\hline \multirow[t]{3}{*}{ NCT03।49822 } & \multirow[t]{3}{*}{$\mathrm{I} / \mathrm{II}$} & \multirow[t]{3}{*}{ Metastatic RCC } & $\begin{array}{l}\text { Phase I: Pembrolizumab } \\
(200 \mathrm{mg})+\text { Cabozantinib } \\
(40 \mathrm{mg})\end{array}$ & \multirow[t]{3}{*}{ ORR } & \multirow{3}{*}{$\begin{array}{l}\text { Maximum Tolerated Dose (MTD), } \\
\text { toxicities, PFS, progression of overall } \\
\text { disease, clinical benefit rate, } \\
\text { recommended phase } 2 \text { dose, duration } \\
\text { on treatment beyond treatment } \\
\text { progression }\end{array}$} & \multirow[t]{3}{*}{ June 2020} \\
\hline & & & $\begin{array}{l}\text { Phase I: Pembrolizumab } \\
(200 \mathrm{mg})+\text { Cabozantinib } \\
(60 \mathrm{mg})\end{array}$ & & & \\
\hline & & & $\begin{array}{l}\text { Phase 2: Pembrolizumab } \\
(200 \mathrm{mg})+\text { Cabozantinib } \\
\text { (recommender phase } 2 \\
\text { dose) }\end{array}$ & & & \\
\hline NCT03200587 & $\mathrm{lb}$ & Metastatic RCC & $\begin{array}{l}\text { Avelumab + Cabozantinib } \\
(20,40 \text {, or } 60 \mathrm{mg})\end{array}$ & $\begin{array}{l}\text { Recommended } \\
\text { phase II dose }\end{array}$ & PFS & September 2022 \\
\hline \multirow[t]{2}{*}{$\begin{array}{l}\text { COSMIC-3I3 } \\
\text { (NCT03937219) }\end{array}$} & \multirow[t]{2}{*}{ III } & \multirow{2}{*}{$\begin{array}{l}\text { Previously untreated } \\
\text { intermediate- or poor- } \\
\text { risk advanced or } \\
\text { metastatic RCC }\end{array}$} & $\begin{array}{l}\text { Cabozantinib + } \\
\text { Nivolumab + Ipilimumab }\end{array}$ & \multirow[t]{2}{*}{ PFS } & \multirow[t]{2}{*}{ OS } & \multirow[t]{2}{*}{ June 2024} \\
\hline & & & $\begin{array}{l}\text { Placebo + Nivolumab + } \\
\text { Ipilimumab }\end{array}$ & & & \\
\hline \multirow[t]{2}{*}{ NCT 03428217} & \multirow[t]{2}{*}{ II } & \multirow{2}{*}{$\begin{array}{l}\text { Advanced or metastatic } \\
\text { RCC }\end{array}$} & CB-839 + Cabozantinib & \multirow[t]{2}{*}{ PFS (per IRC) } & \multirow[t]{2}{*}{ OS, PFS (per investigator) } & \multirow[t]{2}{*}{ September 2022} \\
\hline & & & Placebo + Cabozantinib & & & \\
\hline \multirow[t]{3}{*}{$\begin{array}{l}\text { CheckMate 9ER } \\
\text { (NCT03।4II77) }\end{array}$} & \multirow[t]{3}{*}{ III } & \multirow{3}{*}{$\begin{array}{l}\text { Locally advanced or } \\
\text { metastatic RCC with } \\
\text { a clear-cell component } \\
\text { with no prior systemic } \\
\text { therapy for RCC. }\end{array}$} & $\begin{array}{l}\text { Nivolumab + } \\
\text { Cabozantinib }\end{array}$ & \multirow[t]{3}{*}{ PFS } & \multirow[t]{3}{*}{ OS, ORR, AE, Serious AE } & \multirow[t]{3}{*}{ May 2024} \\
\hline & & & $\begin{array}{l}\text { Nivolumab + Ipilimumab } \\
+ \text { Cabozantinib }\end{array}$ & & & \\
\hline & & & Sunitinib & & & \\
\hline
\end{tabular}


Table 4 Ongoing Clinical Trials Investigating Novel Combination Treatment Regimens for HCC

\begin{tabular}{|c|c|c|c|c|c|c|}
\hline Trial Name & Phase & Target Population & Treatment Arms & $\begin{array}{l}\text { Primary } \\
\text { Endpoint }\end{array}$ & Secondary Endpoint & $\begin{array}{l}\text { Estimated } \\
\text { Study } \\
\text { Completion } \\
\text { Date }\end{array}$ \\
\hline \multirow{5}{*}{$\begin{array}{l}\text { CheckMate } 040 \\
\text { (NCT0I658878) }\end{array}$} & \multirow[t]{5}{*}{$1 / I I$} & \multirow{5}{*}{$\begin{array}{l}\text { Untreated, advanced } \\
\mathrm{HCC}\end{array}$} & Nivolumab & \multirow{5}{*}{$\begin{array}{l}\text { Safety \& } \\
\text { tolerability, ORR }\end{array}$} & \multirow{5}{*}{$\begin{array}{l}\text { Complete response rate, disease } \\
\text { control rate, duration of } \\
\text { response, time to response, time } \\
\text { to progression, PFS, OS, PD-LI } \\
\text { expression, pharmacokinetics of } \\
\text { Nivolumab }\end{array}$} & \multirow[t]{5}{*}{ April 2022} \\
\hline & & & Nivolumab + Ipilimumab & & & \\
\hline & & & Nivolumab + Cabozantinib & & & \\
\hline & & & $\begin{array}{l}\text { Nivolumab + Ipilimumab + } \\
\text { Cabozantinib }\end{array}$ & & & \\
\hline & & & Sorafenib & & & \\
\hline NCT03299946 & 1 & Locally advanced HCC & Cabozantinib + Nivolumab & $\begin{array}{l}\text { Number of AE, } \\
\text { number of } \\
\text { patients who } \\
\text { complete pre-op } \\
\text { treatment and } \\
\text { proceed to } \\
\text { surgery }\end{array}$ & $\begin{array}{l}\text { \% of patients who obtain R0 } \\
\text { resection, \% of patients with } \\
\text { complete response, \% of patients } \\
\text { with major pathologic responses, } \\
\text { ORR, OS, disease-free survival }\end{array}$ & March 2022 \\
\hline \multirow[t]{3}{*}{$\begin{array}{l}\text { COSMIC-3I2 } \\
\text { (NCT0375579I) }\end{array}$} & \multirow[t]{3}{*}{ III } & \multirow{3}{*}{$\begin{array}{l}\text { Advanced } \mathrm{HCC} \text { without } \\
\text { previous systemic } \\
\text { therapy }\end{array}$} & $\begin{array}{l}\text { Cabozantinib + Atezolizumab } \\
\text { (experimental) }\end{array}$ & \multirow{3}{*}{$\begin{array}{l}\text { PFS } \\
\text { (experimental vs } \\
\text { control), OS }\end{array}$} & \multirow[t]{3}{*}{ PFS (single-agent vs control) } & \multirow[t]{3}{*}{ December 2021} \\
\hline & & & Sorafenib (control) & & & \\
\hline & & & Cabozantinib (single-agent) & & & \\
\hline $\begin{array}{l}\text { CLEARANCE } \\
(\text { NCT03963206) }\end{array}$ & IV & $\begin{array}{l}\text { Intermediate HCC } \\
\text { (ineligible for } \\
\text { chemoembolization), or } \\
\text { advanced HCC (after } \\
\text { failure of Sorafenib or } \\
\text { another systemic } \\
\text { therapy) }\end{array}$ & $\begin{array}{l}\text { Cabozantinib }(20,40 \text {, or } \\
60 \mathrm{mg})\end{array}$ & os & $\begin{array}{l}A E \text {, daily median dose of } \\
\text { cabozantinib, number of patients } \\
\text { with each dose of cabozantinib }\end{array}$ & September 2021 \\
\hline \multirow[t]{2}{*}{ NCT03586973 } & \multirow[t]{2}{*}{ ॥ } & \multirow[t]{2}{*}{$\begin{array}{l}\text { Advanced } \mathrm{HCC} \text { in } \\
\text { Japanese patients }\end{array}$} & $\begin{array}{l}\text { Cabozantinib (post first-line } \\
\text { progression on sorafenib) }\end{array}$ & \multirow[t]{2}{*}{$\begin{array}{l}\text { 24-week PFS } \\
\text { rate }\end{array}$} & \multirow[t]{2}{*}{$\begin{array}{l}\text { PFS, ORR, disease-control rate, } \\
\text { OS }\end{array}$} & \multirow[t]{2}{*}{ November 2020} \\
\hline & & & $\begin{array}{l}\text { Cabozantinib (treatment- } \\
\text { naïve) }\end{array}$ & & & \\
\hline
\end{tabular}

Table 5 Ongoing Clinical Trials Investigating Novel Combination Treatment Regimens for Both RCC and HCC

\begin{tabular}{|l|l|l|l|l|l|l|}
\hline Trial Name & Phase & Target Population & $\begin{array}{l}\text { Treatment } \\
\text { Arms }\end{array}$ & $\begin{array}{l}\text { Primary } \\
\text { Endpoint }\end{array}$ & $\begin{array}{l}\text { Secondary } \\
\text { Endpoint }\end{array}$ & $\begin{array}{l}\text { Estimated Study } \\
\text { Completion Date }\end{array}$ \\
\hline NCT03170960 & Ib & $\begin{array}{l}\text { Locally advanced, metastatic, or } \\
\text { recurrent solid tumor }\end{array}$ & $\begin{array}{l}\text { Cabozantinib }+ \\
\text { Atezolizumab }\end{array}$ & MTD, ORR & $\begin{array}{l}\text { Incidence and } \\
\text { severity of AE }\end{array}$ & December 2020 \\
\hline
\end{tabular}

metastatic solid tumors, including RCC and HCC. CheckMate040 (NCT01658878) is a phase 1/2 study evaluating the safety, tolerability, and efficacy of nivolumab or nivolumab in combination with other agents (cabozantinib, sorafenib, and ipilimumab) in patients with advanced HCC. Another study (NCT03299946) is exploring neoadjuvant cabozantinib in combination with nivolumab, prior to definitive resection, in patients with locally advanced HCC. The COSMIC-312 (NCT03755791) trial is comparing the efficacy of cabozantinib in combination with atezolizumab versus the standard-of-care sorafenib as first-line treatment for advanced $\mathrm{HCC}$. 
Cabozantinib has proven to be an effective agent in HCC and RCC. At present, cabozantinib is undergoing rapid development through multiple innovative trials that are exploring new avenues such as neoadjuvant treatments, novel combination regimens, and rare RCC histologies. Most of these trials are also incorporating novel biomarker studies to further understand the pathogenesis of these diseases and optimal patient selection for these therapies. These clinical trials have the potential to change the standard of care for HCC and RCC in the near future.

\section{Author Contributions}

All authors made substantial contributions to conception and design, acquisition of data, or analysis and interpretation of data; took part in drafting the article or revising it critically for important intellectual content; gave final approval of the version to be published; and agree to be accountable for all aspects of the work.

\section{Disclosure}

Neeraj Agarwal and Umang Swami are cocorresponding authors. Dr Benjamin L. Maughan reports personal fees from Exelixis, BMS, Astellas, Bayer Oncology, Janssen Oncology, Tempus, Peloton Therapeutics, Clovis, and Merck, during the conduct of the study. Dr Neeraj Agarwal reports consultancy to: Astellas, Astra Zeneca, Bayer, Bristol Myers Squibb, Clovis, Eisai, Eli Lilly, EMD Serono, Exelixis, Foundation Medicine, Genentech, Janssen, Merck, Nektar, Novartis, Pfizer, Pharmacyclics, and Seattle Genetics; research funding to his institution: Astra Zeneca, Bavarian Nordic, Bayer, Bristol Myers Squibb, Calithera, Celldex, Clovis, Eisai, Eli Lilly, EMD Serono, Exelixis, Genentech, Glaxo Smith Kline, Immunomedics, Janssen, Medivation, Merck, Nektar, New Link Genetics, Novartis, Pfizer, Prometheus, Rexahn, Roche, Sanofi, Seattle Genetics, Takeda, and Tracon.The authors report no other conflicts of interest in this work.

\section{References}

1. Lemmon MA, Schlessinger J. Cell signaling by receptor tyrosine kinases. Cell. 2010;141(7):1117-1134. doi:10.1016/j.cell.2010.06.011

2. Koch S, Claesson-Welsh L. Signal transduction by vascular endothelial growth factor receptors. Cold Spring Harb Perspect Med. 2012;2 (7):a006502. doi:10.1101/cshperspect.a006502

3. Krock BL, Skuli N, Simon MC. Hypoxia-induced angiogenesis: good and evil. Genes Cancer. 2011;2(12):1117-1133. doi:10.1177/19476019114 23654
4. Lu KV, Chang J, Parachoniak C, et al. VEGF inhibits tumor cell invasion and mesenchymal transition through a MET/VEGFR2 complex. Cancer Cell. 2012;22(1):21-35. doi:10.1016/j.ccr.2012.05.037

5. Yakes FM, Chen J, Tan J, et al. Cabozantinib (XL184), a novel MET and VEGFR2 inhibitor, simultaneously suppresses metastasis, angiogenesis, and tumor growth. Mol Cancer Ther. 2011;10 (12):2298-2308. doi:10.1158/1535-7163.MCT-11-0264

6. Desai A, Small EJ. Treatment of advanced renal cell carcinoma patients with cabozantinib, an oral multityrosine kinase inhibitor of MET, AXL and VEGF receptors. Future Oncol. 2019;15 (20):2337-2348. doi:10.2217/fon-2019-0021

7. Lacy SA, Miles DR, Nguyen LT. Clinical pharmacokinetics and pharmacodynamics of cabozantinib. Clin Pharmacokinet. 2017;56 (5):477-491. doi:10.1007/s40262-016-0461-9

8. Hsieh JJ, Le VH, Oyama T, Ricketts CJ, Ho TH, Cheng EH, Chromosome $3 p$ loss-orchestrated VHL, HIF, and epigenetic deregulation in clear cell renal cell carcinoma. J Clin Oncol. 2018;JCO2018792549.

9. Kaelin WG Jr. The von Hippel-Lindau tumour suppressor protein: O2 sensing and cancer. Nat Rev Cancer. 2008;8(11):865-873. doi:10.1038/ $\operatorname{nrc} 2502$

10. Zhou L, Liu X-D, Sun M, et al. Targeting MET and AXL overcomes resistance to sunitinib therapy in renal cell carcinoma. Oncogene. 2016;35(21):2687-2697. doi:10.1038/onc.2015.343

11. Nguyen L, Benrimoh N, Xie Y, et al. Pharmacokinetics of cabozantinib tablet and capsule formulations in healthy adults. Anticancer Drugs. 2016;27(7):669-678. doi:10.1097/CAD.00000 00000000366

12. Nguyen L, Holland J, Mamelok R, et al. Evaluation of the effect of food and gastric $\mathrm{pH}$ on the single-dose pharmacokinetics of cabozantinib in healthy adult subjects. J Clin Pharmacol. 2015;55 (11):1293-1302. doi:10.1002/jcph.526

13. Nguyen L, Holland J, Ramies D, et al. Effect of renal and hepatic impairment on the pharmacokinetics of cabozantinib. $J$ Clin Pharmacol. 2016;56(9):1130-1140. doi:10.1002/jcph.714

14. Choueiri TK, Pal SK, McDermott DF, et al. A phase I study of cabozantinib (XL184) in patients with renal cell cancer. Ann Oncol. 2014;25(8):1603-1608. doi:10.1093/annonc/mdu184

15. Motzer RJ, Hutson TE, Cella D, et al. Pazopanib versus sunitinib in metastatic renal-cell carcinoma. $N$ Engl J Med. 2013;369(8):722-731. doi:10.1056/NEJMoa1303989

16. Rini BI, Escudier B, Tomczak P, et al. Comparative effectiveness of axitinib versus sorafenib in advanced renal cell carcinoma (AXIS): a randomised Phase 3 trial. Lancet. 2011;378(9807):1931-1939. doi:10.1016/S0140-6736(11)61613-9

17. Choueiri TK, Escudier B, Powles T, et al. Cabozantinib versus Everolimus in Advanced Renal-Cell Carcinoma. $N$ Engl $\mathrm{J}$ Med. 2015;373(19):1814-1823. doi:10.1056/NEJMoa1510016

18. Motzer RJ, Escudier B, Powles T, et al. Long-term follow-up of overall survival for cabozantinib versus everolimus in advanced renal cell carcinoma. Br J Cancer. 2018;118(9):1176-1178. doi:10.1038/s41416018-0061-6

19. Choueiri TK, Escudier B, Powles TL, et al. Cabozantinib versus everolimus in advanced renal cell carcinoma (METEOR): final results from a randomised, open-label, phase 3 trial. Lancet Oncol. 2016;17(7):917-927. doi:10.1016/S1470-2045(16)30107-3

20. Donskov F, Motzer RJ, Voog E, et al. Outcomes based on age in the phase III METEOR trial of cabozantinib versus everolimus in patients with advanced renal cell carcinoma. Eur $J$ Cancer. 2019;126:1-10. doi:10.1016/j.ejca.2019.10.032

21. Hale P, Hahn AW, Rathi N, et al. Treatment of metastatic renal cell carcinoma in older patients: a network meta-analysis. $J$ Geriatr Oncol. 2019;10(1):149-154. doi:10.1016/j.jgo.2018.05.010

22. Powles T, Motzer RJ, Escudier B, et al. Outcomes based on prior therapy in the phase 3 METEOR trial of cabozantinib versus everolimus in advanced renal cell carcinoma. Br J Cancer. 2018;119 (6):663-669. doi:10.1038/s41416-018-0164-0 
23. Flaifel A, Xie W, Braun DA, et al. PD-L1 expression and clinical outcomes to cabozantinib, everolimus, and sunitinib in patients with metastatic renal cell carcinoma: analysis of the randomized clinical trials METEOR and CABOSUN. Clin Cancer Res. 2019;25 (20):6080-6088. doi:10.1158/1078-0432.CCR-19-1135

24. Choueiri TK, Halabi S, Sanford BL, et al. Cabozantinib versus sunitinib as initial targeted therapy for patients with metastatic renal cell carcinoma of poor or intermediate risk: the alliance A031203 CABOSUN trial. J Clin Oncol. 2017;35(6):591-597. doi:10.1200/ JCO.2016.70.7398

25. Choueiri TK, Hessel C, Halabi S, et al. Cabozantinib versus sunitinib as initial therapy for metastatic renal cell carcinoma of intermediate or poor risk (Alliance A031203 CABOSUN randomised trial): progression-free survival by independent review and overall survival update. Eur J Cancer. 2018;94:115-125. doi:10.1016/j.ejca.2018.02.012

26. Nakamura T, Nishizawa T, Hagiya M, et al. Molecular cloning and expression of human hepatocyte growth factor. Nature. 1989;342 (6248):440-443. doi:10.1038/342440a0

27. Zhang SZ, Pan FY, Xu JF, et al. Knockdown of c-Met by adenovirus-delivered small interfering RNA inhibits hepatocellular carcinoma growth in vitro and in vivo. Mol Cancer Ther. 2005;4 (10):1577-1584. doi:10.1158/1535-7163.MCT-05-0106

28. Daveau M, Scotte M, François A, et al. Hepatocyte growth factor, transforming growth factor $\alpha$, and their receptors as combined markers of prognosis in hepatocellular carcinoma. Mol Carcinog. 2003;36(3):130-141. doi:10.1002/mc.10103

29. Llovet JM, Ricci S, Mazzaferro V, et al. Sorafenib in advanced hepatocellular carcinoma. $N$ Engl J Med. 2008;359(4):378-390. doi:10.1056/NEJMoa0708857

30. Firtina Karagonlar Z, Koc D, Iscan E, et al. Elevated hepatocyte growth factor expression as an autocrine c-Met activation mechanism in acquired resistance to sorafenib in hepatocellular carcinoma cells. Cancer Science. 2016;107(4):407-416. doi:10.1111/cas.12891

31. Kelley RK, Verslype C, Cohn AL, et al. Cabozantinib in hepatocellular carcinoma: results of a Phase 2 placebo-controlled randomized discontinuation study. Ann Oncol. 2017;28(3):528-534. doi:10.1093/ annonc/mdw651

32. Schoffski P, Gordon M, Smith DC, et al. Phase II randomised discontinuation trial of cabozantinib in patients with advanced solid tumours. Eur J Cancer. 2017;86:296-304. doi:10.1016/j.ejca.2017. 09.011

33. Abou-Alfa GK, Meyer T, Cheng A-L, et al. Cabozantinib in patients with advanced and progressing hepatocellular carcinoma. $N$ Engl J Med. 2018;379(1):54-63. doi:10.1056/NEJMoa1717002

34. Kelley RK, Rimassa L, Ryoo B-Y, et al. Alpha fetoprotein (AFP) response and efficacy outcomes in the phase III CELESTIAL trial of cabozantinib $(\mathrm{C})$ versus placebo $(\mathrm{P})$ in advanced hepatocellular carcinoma (HCC). J Clin Oncol. 2019;37(4_suppl):423. doi:10.1200/ JCO.2019.37.4_suppl.423
35. Abou-Alfa GK, Meyer T, Cheng A-L, et al. Association of adverse events (AEs) with efficacy outcomes for cabozantinib (C) in patients (pts) with advanced hepatocellular carcinoma (aHCC) in the phase III CELESTIAL trial. J Clin Oncol. 2019;37(15_suppl):4088. doi:10.120 0/JCO.2019.37.15_suppl.4088

36. Abou-Alfa GK, Mollon P, Meyer T, et al. Quality-adjusted life years assessment using cabozantinib for patients with advanced hepatocellular carcinoma (aHCC) in the CELESTIAL trial. J Clin Oncol. 2019;37(4 suppl):207. doi:10.1200/JCO.2019.37.4 suppl.207

37. Rosenzweig SA. Acquired resistance to drugs targeting receptor tyrosine kinases. Biochem Pharmacol. 2012;83(8):1041-1048. doi:10.1016/j.bcp.2011.12.025

38. Jiao Q, Bi L, Ren Y, et al. Advances in studies of tyrosine kinase inhibitors and their acquired resistance. Mol Cancer. 2018;17(1):36. doi:10.1186/s12943-018-0801-5

39. Huaqi Y, Caipeng Q, Qiang W, et al. Transcription factor SOX18 promotes clear cell renal cell carcinoma progression and alleviates cabozantinib-mediated inhibitory effects. Mol Cancer Ther. 2019;18 (12):2433-2445. doi:10.1158/1535-7163.MCT-19-0043

40. Lee YC, Lin S-C, Yu G, et al. Identification of bone-derived factors conferring de novo therapeutic resistance in metastatic prostate cancer. Cancer Res. 2015;75(22):4949-4959. doi:10.1158/00085472.CAN-15-1215

41. Varkaris A, Corn PG, Parikh NU, et al. Integrating murine and clinical trials with cabozantinib to understand roles of MET and VEGFR2 as targets for growth inhibition of prostate cancer. Clin Cancer Res. 2016;22(1):107-121. doi:10.1158/1078-0432.CCR-150235

42. Koinis F, Corn P, Parikh N, et al. Resistance to MET/VEGFR2 inhibition by cabozantinib is mediated by YAP/TBX5-dependent induction of FGFR1 in castration-resistant prostate cancer. Cancers (Basel). 2020;12(1):244.

43. Yu KJ, Li JK, Lee Y-C, et al. Cabozantinib-induced osteoblast secretome promotes survival and migration of metastatic prostate cancer cells in bone. Oncotarget. 2017;8(43):74987-75006. doi:10.18632/ oncotarget.20489

44. Bahcall M, Kuang Y, Paweletz CP, Jänne PA. Abstract 4100: mechanisms of resistance to type I and type II MET inhibitors in non-small cell lung cancer. Cancer Res. 2017;77(13 Supplement):4100.

45. Somwar R, Smith R, Hayashi T, et al. MDM2 amplification (Amp) to mediate cabozantinib resistance in patients (Pts) with advanced RET-rearranged lung cancers. J Clin Oncol. 2016;34(15_suppl):9068. doi:10.1200/JCO.2016.34.15_suppl.9068

46. Fuse MJ, Okada K, Oh-hara T, et al. Mechanisms of resistance to NTRK inhibitors and therapeutic strategies in NTRK1-rearranged cancers. Mol Cancer Ther. 2017;16(10):2130-2143. doi:10.1158/ 1535-7163.MCT-16-0909

\section{Publish your work in this journal}

Cancer Management and Research is an international, peer-reviewed open access journal focusing on cancer research and the optimal use of preventative and integrated treatment interventions to achieve improved outcomes, enhanced survival and quality of life for the cancer patient.
The manuscript management system is completely online and includes a very quick and fair peer-review system, which is all easy to use Visit http://www.dovepress.com/testimonials.php to read real quotes from published authors. 